\title{
To the Arctic, For the Arctic
}

\author{
Tracey L. Anderson*
}

Grant MacEwan University, Canada

The Earth does not speak with words like humans do. But it does communicate-if only humans would stop, look, and listen to the sights and sounds that Earth presents us. In our society, a myth still exists in many quarters that global warming is not real. Many people believe that myth, such as Fox News commentator Sean Hannity, who told viewers "[Vice President Al Gore] doesn't think there's room for debate on climate change. I do. The debate's over. There's no global warming" (as cited in Media Matters for America, 2011). These people are averting their eyes, closing their ears to the evidence. To the Arctic (Judson, MacGillivray \& MacGillivray, 2011), the new documentary in IMAX format, which stands for Image Maximum, "a motion picture

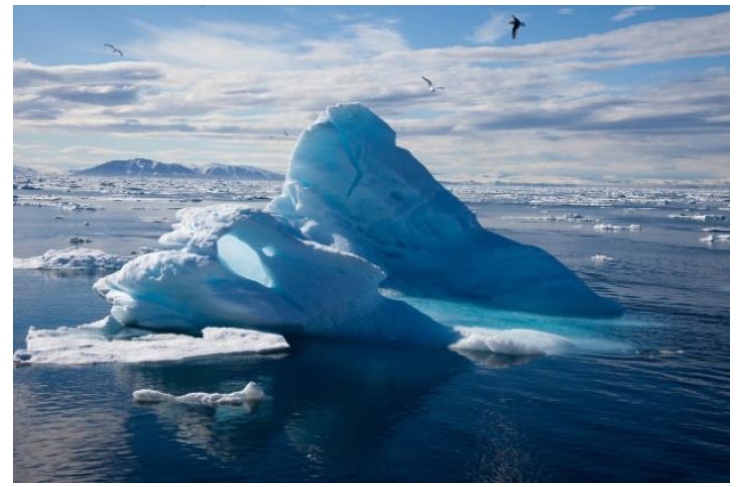
format with the capacity for greater size and clearer resolution than standard movie systems" (Tech-FAQ, 2012), reveals the verifiable impacts of global warming on the Arctic so that humans can see and hear them up close. Once we have seen and heard these sights and sounds, perhaps we will finally heed the message in them.

Figure 1: Arctic ice

Source: http://www.imax.com/tothearctic/site.html\#

To the Arctic, directed by Greg MacGillivray and produced by his son Shaun MacGillivray, is a visually stunning film. It is also emotionally stunning. It is a must-see for anyone who doubts that global warming is real. Narrator Meryl Streep takes us to the Arctic to present its landscape and climate, which is changing so quickly that "if you look at NOAA's [National Oceanic and Atmospheric Administration] reports from satellite, 
you see how it has changed every year, getting less and less ice during the summer in the polar ice cap.... where we went, 25 years ago, there would have been tons of ice. Now there isn't that much" (S. MacGillivray, in Loose, 2012).

The film's overhead shots of deep cracks in the ice shelf through which melt water rushes and then gushes over the edge in dozens upon dozens of waterfalls leaves no doubt about the impact of warming on the ice. Greg MacGillvray explains, "The ice cap is melting from both the top, due to the sun, and from the bottom because the ocean is warming. Because the ocean is dark, relative to the ice, it absorbs the sun's heat" (G. MacGillivray, in Loose, 2012). The rushing water is the Arctic's cry for help.

This film shows us the Arctic's increasingly endangered wildlife. Although we see cavorting caribou and wallowing walruses, the spotlight is on polar bears, specifically a mother polar bear and her two cubs, less than a year old. Phenomenally, this polar family allowed the IMAX crew to shoot footage of them for nearly a week, offering audiences a rare prolonged look at their habits and habitat. Some of the most entertaining and engaging film footage shows the bears playing with the various camerahiding devices the crew used to disguise their equipment. Like young children overcome by curiosity, the bears were intrigued and treated the camouflaged tools like toys, eventually cracking at least one of the canisters open to check what was inside.

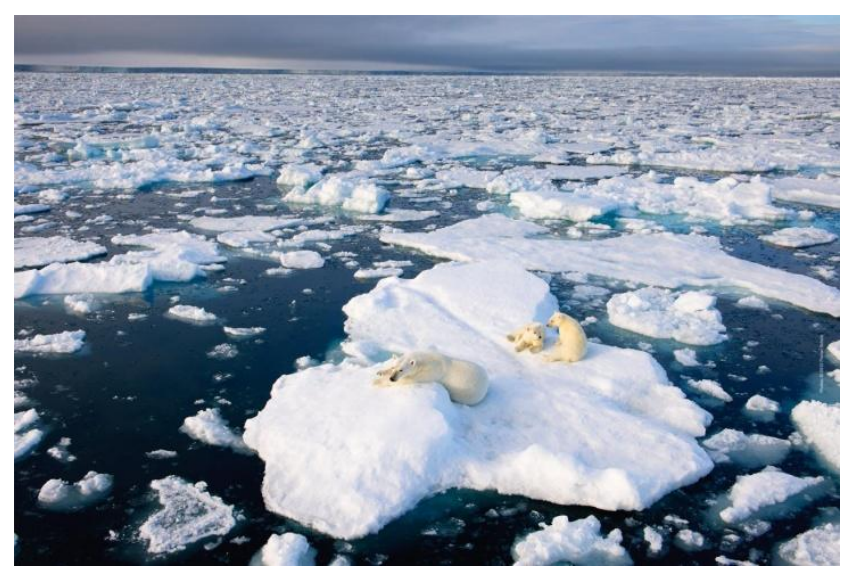

Figure 2: The polar bear family featured in the film Source: http://www.imax.com/tothearctic/site.html\#

While the film certainly has its endearing moments filled with laughter, loved by adults and children alike, it is also filled with suspense. In one distressing sequence, the mother bear and her cubs are stalked relentlessly by a lone adult male polar bear, willing to hunt and eat the vulnerable cubs because his own food sources are shrinking due to global warming. "The polar bear requires sea ice to hunt its primary food source, the ringed seal," (IMAX, n.d., Curriculum Guide, p. 8); less ice, therefore, means less food. Viewers' emotions are torn between hope that the cubs survive and sympathy for the adult male who is hungry and in danger of dying from lack of food. The conflict is 
upsetting; it also illustrates the myriad ways that animals in the Arctic are at risk from the warming climate.

To the Arctic is also full of despair. The beautiful, barren footage is all the more poignant because global warming is slowly destroying the habitat of these unique creatures - the habitat they were built for and the only one they can survive in. Although polar bears are adapted to life in this environment, "survival is a task made more formidable by the stress of a disappearing habitat" (IMAX, n.d., Curriculum Guide, p. 3). Viewers are immersed in a majestic, fragile splendour that we cannot help but realize may one day cease, perhaps in our lifetimes. The realization is cruel and crushing.

Although this film has moments of tension, its imagery and content is suitable for school-aged children. In truth, parents should accompany their children, and teachers should arrange trips for their students to see this film. It teaches necessary lessons about global warming in a way everyone can understand and opens an avenue for discussion after the film ends. Since children will make our society's choices in the future, this meaningful conversation is a crucial one to begin now.

Although many scientists are studying the wildlife of the Arctic, such as Dr. Steven C. Amstrup of Polar Bears International (2012) and Dr. Steve Ferguson of the Freshwater Institute Science Laboratory (Fisheries and Oceans Canada, 2009), no one currently knows with certainty what the future holds for the animals of the Arctic. We can only speculate what will happen if warming in the region continues at its current pace of "twice as fast as everywhere else on the planet" (G. MacGillivray, in Loose, 2012). The producers of To the Arctic have given us grim glimpses of what the world may experience; they have provided the lens through which we can see the bleak images and the soundtrack through which we can hear the straining sounds of global warming's impacts on this beautiful northern land. Through what the Earth is showing us in the Arctic, she is speaking to us, asking for help. Will we heed the call?

To view the official movie trailer for To the Arctic you can visit the following website: http://www.imax.com/tothearctic/site.html

*Writer: Tracey L. Anderson is an editor for Earth Common Journal and is currently completing her third year in the Bachelor of Applied Communications in Professional Writing degree program at Grant MacEwan University. She is also a former English as a second language teacher who taught in China, Macedonia, Morocco, and the United Arab Emirates.

ECJ Volume 2, No. 1, 2012 


\section{References}

Fisheries and Oceans Canada. (2009, September 4). Scientists Directory: Steve Ferguson. Retrieved from http://www.meds-sdmm.dfo-mpo.gc.ca/sdb-bds/profileprofil.do?id $=448 \&$ lang=eng

Imax. (n.d.) IMAX: To the Arctic. Retrieved from http:/ /www.imax.com/tothearctic/site.html\#

Imax. (n.d.) To the Arctic Curriculum Guide for Teachers. Retrieved from http://www.imax.com/tothearctic/downloads/IMAX_ToTheArctic_CurriculumG uide.pdf

Judson, S. (Writer/Editor), MacGillivray, G. (Director), \& MacGillivray, S. (Producer). (2011). To the Arctic [Motion Picture]. Warner Brothers Entertainment.

Loose, T. (2012, April 25). Interview with Greg and Shaun MacGillivray. Coast Magazine. Retrieved from http:/ / www.coastmagazine.com/articles/macgillivray-2153--.html

Media Matters for America. (2011, February 1). Fox News' Top 10 Lies About Climate Science. Retrieved from http://mediamatters.org/research/2011/02/01/fox-newstop-10-lies-about-climate-science/175811

Polar Bears International. (2012). Meet the Polar Bear Scientists. Retrieved from http://www.polarbearsinternational.org/research/scientists/meet-the-scientists Tech-FAQ. (2012). IMAX. Retrieved from http://www.tech-faq.com/imax.html 